\title{
Prediction of Protection against Asian Enterovirus 71 Outbreak Strains by Cross-neutralizing Capacity of Serum from Dutch Donors, the Netherlands
}

\author{
Sabine M.G. van der Sanden, Gerrit Koen, Hetty van Eijk, Sylvie M. Koekkoek, \\ Menno D. de Jong, Katja C. Wolthers
}

Outbreaks of human enterovirus 71 (EV-71) in Asia are related to high illness and death rates among children. To gain insight into the potential threat for the population of Europe, we determined the neutralizing activity in intravenous immunoglobulin (IVIg) batches and individual serum samples from donors in the Netherlands against EV-71 strains isolated in Europe and in Asia. All IVIg batches and 41\%, 79\%, and $65 \%$ of serum samples from children $\leq 5$ years of age, women of childbearing age, and HIV-positive men, respectively, showed high neutralizing activity against a Dutch C1 strain, confirming widespread circulation of EV-71 in the Netherlands. Asian B3-4 and C4 strains were efficiently cross-neutralized, predicting possible protection against extensive circulation and associated outbreaks of those types in Europe. However, C2 and C5 strains that had few mutations in the capsid region consistently escaped neutralization, emphasizing the importance of monitoring antigenic diversity among circulating EV-71 strains.

Qnterovirus $71(\mathrm{EV}-71)$ is a member of the genus EnUterovirus, family Picornaviridae, and is a major causative agent of hand, foot and mouth disease in children $\leq 5$ years of age. The virus may also invade the central nervous system and cause severe neurologic disease, including paralysis and brainstem encephalitis (1). On the basis of nucleotide sequence diversity in the viral protein (VP)1 capsid gene, 7 EV-71 genogroups $(\mathrm{A}-\mathrm{G})$ have been defined $(2,3)$. Genogroup A contains a prototype strain that was isolated in the United States in 1969; additional strains of this genogroup were identified in China in May 2008 (4). Genogroup $\mathrm{B}$ and $\mathrm{C}$ viruses have been circulating more widely and contain 6 and 5 genotypes, respectively, defined as B0-B5 and C1-C5. Within genotype C4, 2 additional subgenotypes have been classified, $\mathrm{C} 4 \mathrm{a}$ and $\mathrm{C} 4 \mathrm{~b}$ (2). The

Author affiliation: Academic Medical Center, Amsterdam, the Netherlands

DOI: http://dx.doi.org/10.3201/eid2209.151579 genogroups $\mathrm{D}$ and $\mathrm{G}$ in India and genogroups $\mathrm{E}$ and $\mathrm{F}$ in Africa were identified more recently $(2,3)$.

The incidence of EV-71 infection has greatly increased in the Asia-Pacific region since 1997. Multiple countries within this region have documented massive outbreaks of EV-71, reporting thousands of cases of severe illness and death among children (1). The increased incidence coincided with the identification of new genotypes (B3-5, C3-5) (5). Although strains of genotypes $\mathrm{C} 4$ and B5 have been isolated from patient samples in Europe, widespread circulation of new genotypes and associated massive outbreaks are restricted to the Asian Pacific region (5-10). Most EV71 strains circulating in Europe belong to genotypes $\mathrm{C} 1$ and $\mathrm{C} 2$, and presence of herd immunity conferred by cross-protective antibodies induced by these types could explain the limited spread of new genotypes. However, this hypothesis has not been formally studied. Multiple studies have reported cross-neutralization, but antigenic diversity among different EV-71 genotypes has also been observed (11-17). These studies have mostly been conducted by using serum samples from Asian donors or animals immunized with Asian outbreak strains.

Intravenous administration of human immunoglobulin (IVIg) is currently the only option to treat persons with severe enterovirus infections. For that, the determination of the neutralizing capacity of IVIg batches against locally circulating strains is of clinical importance. Furthermore, IVIg used in the Netherlands contains plasma from $>1,000$ healthy Dutch donors and so represents the immunologic profile of the general population against specific pathogens. To gain more insight into the potential threat of Asian EV-71 outbreak strains for the European population and the potential treatment efficacy of IVIg, we determined the cross-neutralizing capacity of IVIg batches composed of plasma from the general population of the Netherlands during 2005-2014 against EV-71 subtypes circulating in Europe or Asia and compared results to IVIg batches from 
Japanese and Vietnamese donors. Furthermore, we determined neutralizing antibody $(\mathrm{nAb})$ titers against EV-71 in serum samples from Dutch donors representing groups that are vulnerable for EV-71 infection but that are not or might not be present in large numbers in the IVIg pools. These include children $\leq 5$ years of age, the main target group for enterovirus infections, and women of childbearing age who had a high probability of exposure by contact with young children. We also included serum samples from HIV-infected men in the analyses to determine EV-71 seroprevalence in a background population with an estimated average exposure to enteroviruses and without increased risk for enterovirus infections. Analysis of the complete capsid encoding regions of EV-71 strains included in the serologic analyses provided possible explanations for observed differences in $\mathrm{nAb}$ titers.

\section{Materials and Methods}

\section{Cells and Virus Strains}

Serum neutralization assays were performed by using rhabdomyosarma (RD), human colorectal adenocarcinoma (HT-29) and African green monkey kidney (Vero) cells (American Type Culture Collection, https://www. atcc.org/). Cell lines were cultured at $37^{\circ} \mathrm{C}, 5 \%$ carbon dioxide $\left(\mathrm{CO}_{2}\right)$ in Eagle's minimum essential medium (EMEM; Lonza, Verviers, Belgium) supplemented with $10 \%$ fetal bovine serum (FBS, Sigma-Aldrich, Zwijndrecht, Netherlands), $100 \mathrm{IU} / \mathrm{mL}$ of penicillin, and 100 $\mu \mathrm{g} / \mathrm{mL}$ of streptomycin. EV-71 strains C1 91-480 and C2 07-2485 (provided by the National Institute for Public Health and the Environment, Bilthoven, The Netherlands), were isolated from clinical specimens in 1991 and 2007 , respectively, by the national enterovirus surveillance system in the Netherlands $(10,18)$. Strains C2 2105-1721 and C2 2105-2503 were isolated as part of primary diagnostics at the Academic Medical Center (AMC) in Amsterdam in 2010. The B3 SK-EV006 and B4 C7-Osaka strains were isolated in Malaysia and Japan in 1997. Strain C4 75-Yamagata was isolated in Japan in 2003, and strain C5 209-VN in Vietnam in 2006.

\section{IVlg Batches and Serum Samples}

IVIg batches composed of plasma from Dutch or Asian donors were tested for their cross-neutralizing capacity against EV-71 strains isolated in the Netherlands and Asia. Six batches from Dutch donors were included (Nanogam, Sanquin, the Netherlands): 1 each from 2005, 2009, and 2014 and 3 from 2010. Batches from Asian donors were 2 from Japan (Teijin Institute for Bio-Medical Research, Hino, Tokyo, Japan; year of manufacture unknown) and 1 from Vietnam from 2011 (Green Cross Corporation, Pymepharco, Vietnam). Along with the IVIg batches, a previously described rabbit polyclonal serum against EV-71 C1 91-480 was included in the neutralization assays (16). Individual human serum samples used for this study were collected and stored at $-20^{\circ} \mathrm{C}$ as part of primary virus diagnostics in the Laboratory of Clinical Virology at AMC during 2010-2014. We defined 2 groups vulnerable for EV-71 infection: children $\leq 5$ years of age, and women of childbearing age who were admitted to the obstetrics ward and had a high probability of exposure to young children. HIV-positive men receiving treatment who regularly attended the outpatient clinic for HIV care were included to study seroprevalence in a background population. A total of 177 samples (on average 12 serum samples/year) were randomly selected from these groups; those from children $\leq 5$ years of age showed a proportional distribution of ages for each year. None of the patients selected had been diagnosed with hand, foot and mouth disease or had positive results for routine EV diagnostic tests.

According to laws in the Netherlands, no ethical approval is required for anonymous use of biobanked specimens. The study was conducted according to the Dutch code of conduct for responsible use of human tissue for medical research 2011 (http://www.federa.org/codegoed-gebruik-van-lichaamsmateriaal-2011) and the AMC Research Code (https://www.amc.nl/web/AMC-website/ Research-Code/).

\section{Serum Neutralization Assays}

EV-71 nAb titers of IVIg batches and individual human serum samples were determined by using a serum neutralization assay. Human serum samples were heat inactivated at $56^{\circ} \mathrm{C}$ for $30 \mathrm{~min}$. A 2-fold serial dilution of the serum samples was subsequently incubated with an equal volume of chloroform-treated $10050 \%$ cell culture infectious doses of virus at $37^{\circ} \mathrm{C}$ in $5 \% \mathrm{CO}_{2}$ for $1 \mathrm{~h}$. HT29, RD, or Vero cells in EMEM supplemented with 10\% FBS were subsequently added and plates were incubated at $37^{\circ} \mathrm{C}$ in $5 \% \mathrm{CO}_{2}$ for 5 $\mathrm{d}$. The neutralizing titer was calculated on the basis of the number of wells showing cytopathogenic effect by using the Spearman-Karber method and reported as the reciprocal titers of serum dilutions that exhibited $50 \%$ neutralization. A neutralizing titer of $\geq 1: 16$ was used as a threshold for seropositivity, because this titer has been correlated with protection against EV-71-associated disease in phase III clinical trials with EV-71 vaccines (2).

\section{Plaque Assay}

Preliminary data indicated that several EV-71 strains escaped neutralization by IVIg batches and individual human serum samples. To exclude presence of non-EV-71 virus strains in our virus stocks, $3,00050 \%$ cell culture infectious doses of the EV-71 virus strains escaping neutralization 
and a strain that was neutralized as a positive control was incubated with a 1:4 dilution of the rabbit polyclonal serum against EV-71 C1 91-480, a selection of the IVIg batches, or plain medium (control) at $37^{\circ} \mathrm{C}$ in $5 \% \mathrm{CO}_{2}$ for $1 \mathrm{~h}$. In total, $200 \mathrm{~mL}$ of a $0.5 \log _{10}$ serial dilution of the virus and serum mixtures was transferred to a monolayer of Vero cells in a 6-well format and incubated at $37^{\circ} \mathrm{C}$ in $5 \%$ $\mathrm{CO}_{2}$ for $1 \mathrm{~h}$. Cells were subsequently covered with $0.9 \%$ agarose mixed with $2 \times$ concentrated MEM supplemented with $4 \%$ fetal calf serum (1:1 ratio). Plates were incubated at $37^{\circ} \mathrm{C}$ at $5 \% \mathrm{CO}_{2}$ for $48-72 \mathrm{~h}$. Single plaques were harvested and amplified on Vero cells before RNA isolation by using the GenElute Mammalian Total RNA Miniprep Kit (Sigma-Aldrich, Zwijndrecht, the Netherlands) according to the manufacturer's instructions. The viral RNA was subsequently subjected to an enterovirus genotyping PCR as described previously (19).

\section{Capsid Sequence Analysis}

Viral RNA was extracted from $50 \mu \mathrm{L}$ of EV-71 isolates cultured on RD, Vero, or HT-29 cell lines, by using the GenElute Mammalian Total RNA Miniprep Kit (SigmaAldrich), according to the manufacturer's instructions. Viral RNA was eluted in $50 \mu \mathrm{L}$ elution buffer. The capsidencoding regions were PCR amplified in 4 overlapping regions by using genogroup $\mathrm{B}$ - and $\mathrm{C}$-specific primers and a PCR amplification protocol described previously (20). Sequencing of the PCR products was performed by using the ABI Prism BigDye Terminator Cycle Sequencing Ready Reaction Kit version 3.2 (Applied Biosystems, Foster City, CA, USA) on an automated sequencer (Applied Biosystems). Editing of the sequence data and generation of consensus sequences of the capsid region by assembling overlapping DNA sequences determined from both strands was performed by using the ClustalW method implemented in BioEdit version 7.2.5 (21). Nucleotide sequences of EV-71 strains used in the current study are accessible in the Genbank/EMBL/DDBJ nucleotide sequence databases under accession numbers AB552982.1 (C1 91-480), AB552987.1 (C2 2485), KU697333 (C2 1721), KU697334 (C2 2503), KU697335 (C4 75-Yamagata), KU697336 (C5 209-VN), AB469182.1 (B3 SK-EV006), and AB550336.1 (B4 C7-Osaka).

\section{Statistical Analysis}

Differences in titers among the study groups were analyzed by using the Kruskal-Wallis One-Way ANOVA test in GraphPad Prism 5 software (GraphPad Software, San Diego, CA, USA) at a significance level of $\mathrm{p}<0.05$. The $95 \%$ CIs of the proportions of seropositive persons were calculated according to the E.B. Wilson method, using the VassarStats Web site for Statistical Computation (http://vassarstats.net/index.html).

\section{Results}

\section{EV-71 Cross-neutralizing Capacity of IVIg Batches}

As human immunoglobulin batches represent the immunological profile of the general population, we studied the crossneutralizing capacity of IVIg batches composed of plasma from Dutch, Japanese, and Vietnamese donors against EV71 strains isolated in Europe and Asia (Figure 1). All batches had high $\mathrm{nAb}$ titers against the Dutch $\mathrm{C} 1$ strain (mean titer 1:776) and the Asian C4, B3, and B4 strains (mean titers $1: 1176,1: 274$, and 1:181, respectively). However, no neutralizing efficacy was observed against the Dutch C2 strains (isolated in 2007 and 2010) and the Asian C5 strain in any of the batches, including the Vietnamese IVIg batch. The hyperimmune rabbit polyclonal serum against EV-71 C1 91-480 did neutralize the strains, but with several-fold lower titers than observed for C1, C4, B3, and B4 strains (Figure 1). The results remained similar when virus strains were

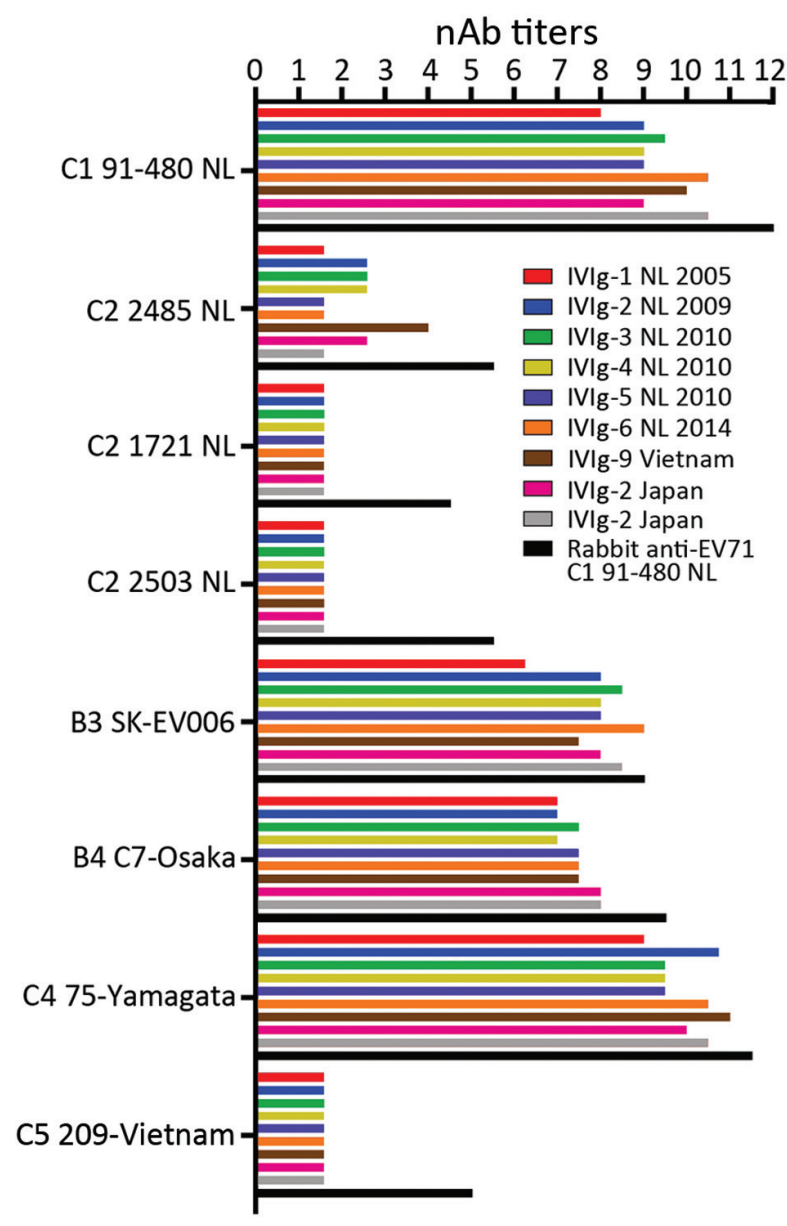

Figure 1. EV-71 nAb titers in IVIg batches composed of plasma from Dutch ( 6 batches), Japanese (2 batches), and Vietnamese ( 1 batch) donors and in a polyclonal rabbit serum against EV-71 C1 91-480. nAb titers are presented as $\log _{2}$ values. EV-71, enterovirus 71; IVIg, intravenous immunoglobulin; nAb, neutralizing antibody; NL, the Netherlands. 
pretreated with chloroform to remove potential virus aggregates or when a different cell line (Vero) was used (data not shown). To exclude presence of non-EV-71 strains in our virus stocks that caused the cytopathogenic effect in the neutralization assays, we plaque-purified viruses incubated with or without the polyclonal serum from rabbits and a selection of the IVIg batches. Genetic characterization confirmed the presence of the EV-71 C2 and C5 genotypes in the virus stocks that escaped neutralization.

\section{EV-71 Neutralizing Antibody Titers in Serum from Dutch Donors}

To determine the level of protection in groups at risk for EV-71 infection, $\mathrm{nAb}$ titers against the Dutch $\mathrm{C} 1$ strain were determined in serum samples from 61 children (median age 2 years, interquartile range [IQR] $1-4$ years) and 56 women of childbearing age (median age 28.6 years, IQR 24.4-34.3 years), collected in the Amsterdam area during 2010-2014. Additionally, serum samples from 60 HIV-positive men (median age 38.2 years, IQR 30-51.7 years), collected during the same years in this region, were included to study seroprevalence in a background population. On average, $41 \%(25 / 61)$ of the children had nAb titers $(\geq 1: 16)$ against EV-71 $\mathrm{C} 1$ (Table 1; Figure 2). Of the 61 children, 3 were $<0.5$ years of age; 2 of those had $n A b$ titers against EV-71, most likely reflecting presence of maternal antibodies. The remaining 58 children were $\geq 0.5-5$ years of age; the percentage of seropositive children was highest in the age group $>2-5$ years $(60.7 \%$ vs. $20 \%$ in the age category $0.5-2$ years). The percentages of seropositive children varied per year. In 2011, 4 (57\%) of the 7 children $0.5-2$ years of age who were tested were found to be seropositive, compared to none in 2010 and 2014. The $\mathrm{nAb}$ titers among children $0.5-2$ years of age (median titer $1: 6$ ) were significantly lower than those for children $>2-5$ years of age (median titer 155; $\mathrm{p}<0.05$ ) (Figure 3).

Among women of childbearing age, 44 (79\%) of 56 were seropositive (median titer 1:64) (Figure 2). Titers within this category significantly differed from those of children $0.5-2$ years of age $(\mathrm{p}<0.05)$ but not from titers of children $>2-5$ years of age.

Of 60 HIV-positive men, 39 (65\%) were seropositive for EV-71 (median titer 1:32). Although titers were lower within this group, they did not significantly differ from those observed among children $>2-5$ years of age or among women of childbearing age.

\section{Cross-neutralizing Capacity of Human Serum}

A selection of individual serum samples with $\mathrm{nAb}$ titers against the EV-71 C1 strain were tested for crossneutralizing activity against heterotypic EV-71 genotypes (Table 2). A total of 17 seropositive serum samples (from 7 children, 4 women, and 6 men) with nAb titers ranging from 1:91 to $1: 2,896$ (mean 1:997), were selected for inclusion on the basis of the volume available for testing multiple EV-71 strains and the titer being high enough to detect several folds lower heterologous nAb titers. Four seronegative serum samples with $\mathrm{nAb}$ titers of $\leq 1: 8$ from 2 children and 2 men were included to study whether serum samples with no nAbs against EV-71 C1 potentially contained nAbs against other EV-71 types. In line with $\mathrm{nAb}$ titers of the IVIg batches, all serum samples from the 17 EV-71 seropositive donors showed nAb titers against the $\mathrm{C} 4$ strain in the range of those observed for the $\mathrm{C} 1$ strain (maximum 2-fold differences, mean titer 1:1,024). High nAb titers, but several-fold lower than those for $\mathrm{C} 4$ strains, were observed for B3 and B4 strains (mean 1:239 and 1:158, respectively). However, the Dutch C2 1721 strain and Vietnamese C5 strain could not be neutralized by any of the serum samples. Serum samples of the 4 donors with $\mathrm{nAb}$ titers of $\leq 1: 8$ against the Dutch $\mathrm{C} 1$ strain did not neutralize any of the strains tested.

\section{Amino Acid Sequence Comparison}

To find explanations for the escape of $\mathrm{C} 2$ and $\mathrm{C} 5$ strains from neutralization, the complete capsid encoding regions

Table 1. Percentages of children $\leq 5 \mathrm{y}$ of age, women of childbearing age, and HIV-positive men with nAb titers against the Dutch enterovirus 71 strain C1 91-480, the Netherlands*

\begin{tabular}{|c|c|c|c|c|c|c|}
\hline \multirow[b]{3}{*}{ Year } & \multicolumn{6}{|c|}{ No. positive/no. tested $(\%, 95 \% \mathrm{Cl})$} \\
\hline & \multicolumn{4}{|c|}{ Children, age, y } & \multicolumn{2}{|c|}{ Adults, characteristics } \\
\hline & $<0.5$ & $0.5-2$ & $>2-5$ & Total $\leq 5$ & F, childbearing age & M, HIV-positive \\
\hline 2010 & $\begin{array}{c}1 / 1 \\
(100,20.6-100)\end{array}$ & $\begin{array}{c}0 / 7 \\
(0,0-35.4)\end{array}$ & $\begin{array}{c}3 / 5 \\
(60.0,23.1-88.2)\end{array}$ & $\begin{array}{c}4 / 13 \\
(30.8,12.7-57.6)\end{array}$ & $\begin{array}{c}10 / 13 \\
(76.9,49.7-91.8)\end{array}$ & $\begin{array}{c}9 / 14 \\
(64.3,38.8-83.7)\end{array}$ \\
\hline 2011 & $\begin{array}{c}1 / 2 \\
(50.0,9.5-90.6)\end{array}$ & $\begin{array}{c}4 / 7 \\
(57.1,25.0-84.2)\end{array}$ & $\begin{array}{c}3 / 6 \\
(50.0,18.8-81.2)\end{array}$ & $\begin{array}{c}8 / 15 \\
(53.3,30.1-75.2)\end{array}$ & $\begin{array}{c}8 / 10 \\
(80.0,49.0-94.3)\end{array}$ & $\begin{array}{c}5 / 10 \\
(50.0,23.7-76.3)\end{array}$ \\
\hline 2012 & $0 / 0$ & $\begin{array}{c}1 / 8 \\
(12.5,2.2-47.1)\end{array}$ & $\begin{array}{c}5 / 6 \\
(83.3,43.7-97.0)\end{array}$ & $\begin{array}{c}6 / 14 \\
(42.9,21.4-67.4)\end{array}$ & $\begin{array}{c}9 / 12 \\
(75.0,46.8-91.1)\end{array}$ & $\begin{array}{c}10 / 14 \\
(71.4,45.4-88.3)\end{array}$ \\
\hline 2013 & $0 / 0$ & $\begin{array}{c}1 / 3 \\
(33.3,6.2-79.2)\end{array}$ & $\begin{array}{c}4 / 8 \\
(50.0,21.5-78.5)\end{array}$ & $\begin{array}{c}5 / 11 \\
(45.5,21.3-71.2)\end{array}$ & $\begin{array}{c}6 / 8 \\
(75.0,40.9-92.9)\end{array}$ & $\begin{array}{c}10 / 14 \\
(71.4,45.4-88.3)\end{array}$ \\
\hline 2014 & $0 / 0$ & $\begin{array}{c}0 / 5 \\
(0,0.0-43.5)\end{array}$ & $\begin{array}{c}2 / 3 \\
(66.7,20.8-93.9)\end{array}$ & $\begin{array}{c}2 / 8 \\
(25.0,7.2-59.1)\end{array}$ & $\begin{array}{c}11 / 13 \\
(84.6,57.8-95.7)\end{array}$ & $\begin{array}{c}5 / 8 \\
(62.5,30.6-86.3)\end{array}$ \\
\hline Total & $\begin{array}{c}2 / 3 \\
(66.7,20.8-93.9)\end{array}$ & $\begin{array}{c}6 / 30 \\
(20.0,9.5-37.3)\end{array}$ & $\begin{array}{c}17 / 28 \\
(60.7,42.4-76.4)\end{array}$ & $\begin{array}{c}25 / 61 \\
(41.0,29.5-53.5)\end{array}$ & $\begin{array}{c}44 / 56 \\
(78.6,66.2-87.3)\end{array}$ & $\begin{array}{c}39 / 60 \\
(65.0,52.4-75.8)\end{array}$ \\
\hline
\end{tabular}




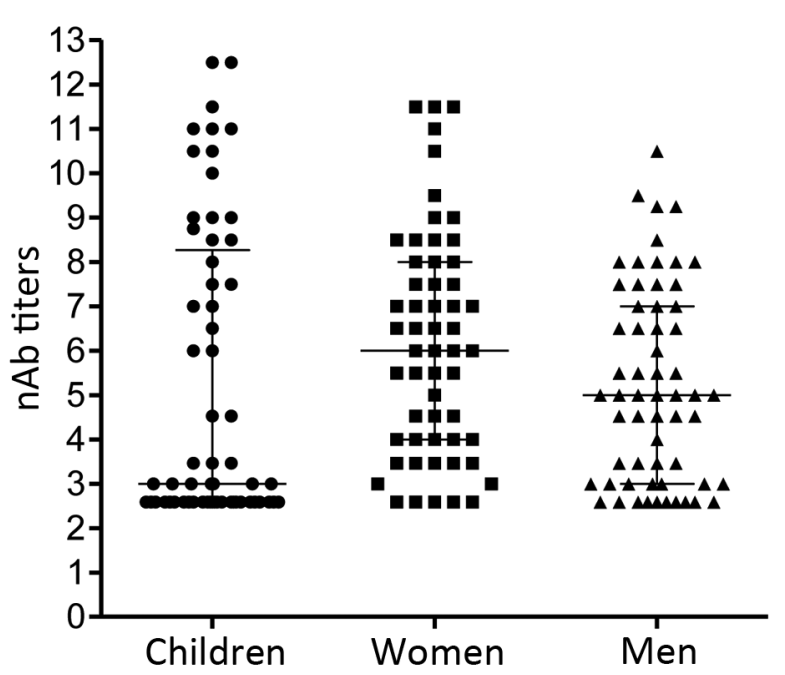

Figure 2. Enterovirus $71 \mathrm{nAb}$ titers in serum collected from Dutch children $\leq 5$ years of age, women of childbearing age, and HIVpositive men during 2010-2014. nAb titers are presented as $\log _{2}$ values. Median titers (wide horizontal lines) with interquartile ranges (error bars) are indicated for each category. $n A b$, neutralizing antibody.

of strains included in this study were sequenced and used for amino acid sequence analysis (Figure 4, http://wwwnc. cdc.gov/EID/article/22/9/15-1579-T4.htm) (22-25). In total, 19 residues differed between the genogroup B and C strains, of which 3 were located in a linear epitope: residues 164, 240, and 241 of VP1 (Figure 4) (22-25). The C2 and C5 strains differed from strains that could be neutralized in residues 145 of VP1 (145E vs. 145G/Q) and 93 of VP3 ( $93 \mathrm{~S}$ vs. $93 \mathrm{~N} / \mathrm{D})$. The $\mathrm{C} 2$ strains had an additional mutation of residue 22 of VP1 (22R vs. 22Q) and the C5 strain of residue 262 of VP1 (262V vs. 262I).

\section{Discussion}

We determined the nAb titers against EV-71 in IVIg batches and individual serum samples from Dutch donors and tested their cross-neutralizing capacity against strains responsible for outbreaks in Asia. The high percentage of EV-71 seropositive serum samples suggests widespread circulation of EV-71 in the Netherlands, which is likely sustained by the presence of a relatively large cohort of susceptible infants $(80 \%$ in the age category $0.5-2$ years). In 2010, EV-71 caused an elevated number of enterovirus infections in the Netherlands, likely explaining the high number of seropositive children in 2011 (18) and in the age category $>2-5$ years in 2012 in this study.

The rates of seropositivity observed in this study are comparable to those observed among the German population $(26,27)$. The prevalence, however, seems not be uniform across Europe, because seroprevalence levels among children in Finland ( $<11$ years of age) and in
European regions of Russia (3-5 years of age) were only $1.6 \%$ and $19 \%-27 \%$,respectively $(6,28)$. The seroprevalence levels observed in the Netherlands are in the range of those observed in Asia before outbreaks (29-33). Although this finding points toward the possibility of large outbreaks in Europe as well, widespread circulation of Asian EV-71 genotypes and associated outbreaks seem to be restricted to the Asian region.

In this study, we showed that IVIg batches and serum samples with $\mathrm{nAb}$ titers against the Dutch $\mathrm{C} 1$ strain efficiently neutralized Asian C4, B3, and B4 strains. This result implies that administration of IVIg from the Netherlands could benefit recovery of a patient infected by an Asian EV-71 strain and could explain why the multiple introductions of genotype $\mathrm{C} 4$ strains in Europe have not resulted in widespread circulation $(6,9,10)$. In agreement with this finding, the transient occurrence of $\mathrm{C} 4$ and $\mathrm{B} 5$ infections in Europe coincided with low population sizes of C1 and C2 (34). However, a relatively large group of susceptible children is still at risk for severe EV-71 infections; therefore, monitoring introduction of new genotypes into Europe remains of importance.

A limitation of our study is that it is not possible to differentiate between neutralization and cross-neutralization. The high neutralizing activity against $\mathrm{C} 4$ strains could reflect actual exposure to $\mathrm{C} 4$ virus rather than cross-neutralization of antibodies induced by $\mathrm{C} 1$ or $\mathrm{C} 2$ strains. This possibility, however, is thought to be negligible, because the systematic, nationwide enterovirus surveillance system in the Netherlands has only reported circulation of $\mathrm{C} 1$ and $\mathrm{C} 2$ strains (10). Additionally, we showed neutralization of the

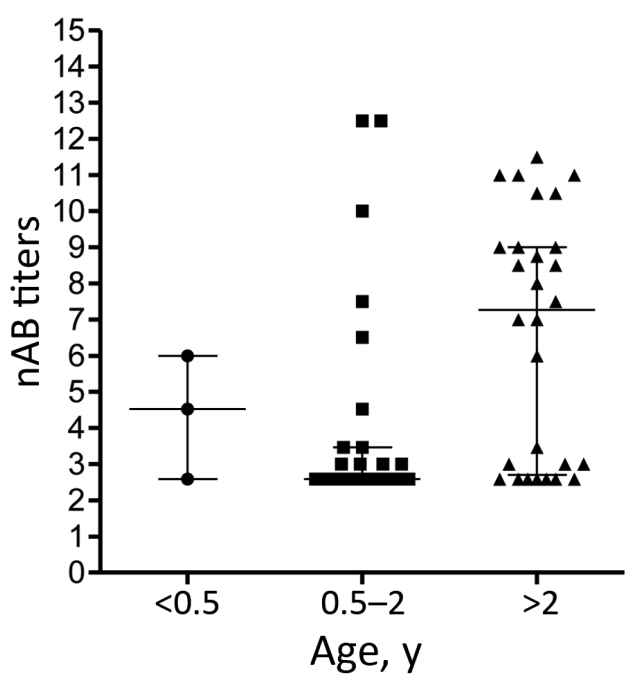

Figure 3. Enterovirus $71 \mathrm{nAb}$ titers in serum collected from Dutch children ( $<0.5$ years, $0.5-2$ years and $>2-5$ years of age) during 2010-2014. nAb titers are presented as $\log _{2}$ values. Median titers (wide horizontal lines) with interquartile ranges (error bars) are indicated for each category. nAb, neutralizing antibody. 
Protection against Asian EV-71 Outbreak Strains

Table 2. Cross-neutralization of heterotypic Asian and Dutch enterovirus 71 strains by serum from Dutch donors, the Netherlands*

\begin{tabular}{|c|c|c|c|c|c|c|c|}
\hline \multirow{2}{*}{$\begin{array}{l}\text { Serum } \\
\text { sample no. }\end{array}$} & \multirow[b]{2}{*}{ Category } & \multicolumn{6}{|c|}{ nAb titers against } \\
\hline & & C1 91-480 NL & $\mathrm{C} 21721 \mathrm{NL}$ & C4 75-Yamagata & C5 209-VN & B3 SK-EV006 & B4 C7-Osaka \\
\hline 1 & Children & 1,448 & NT & 1,448 & NT & 362 & 64 \\
\hline 2 & Children & 362 & NT & 362 & NT & 128 & 45 \\
\hline 3 & Children & 2,048 & NT & 1,448 & NT & 724 & 362 \\
\hline 4 & Children & 1,448 & NT & 1,024 & NT & 512 & 256 \\
\hline 5 & Children & 2,896 & NT & 2,048 & NT & ND & ND \\
\hline 6 & Children & 2,048 & NT & 5,793 & NT & ND & ND \\
\hline 7 & Children & 181 & NT & ND & ND & ND & ND \\
\hline 8 & Women & 2,896 & NT & 1,448 & NT & 181 & 256 \\
\hline 9 & Women & 91 & NT & 91 & NT & 45 & 23 \\
\hline 10 & Women & 724 & NT & 724 & NT & 128 & 362 \\
\hline 11 & Women & 181 & NT & 256 & NT & 32 & 32 \\
\hline 12 & Men & 724 & NT & 512 & NT & 181 & 64 \\
\hline 13 & Men & 609 & NT & 362 & NT & 64 & 91 \\
\hline 14 & Men & 609 & NT & 512 & NT & ND & ND \\
\hline 15 & Men & 256 & NT & 181 & NT & ND & ND \\
\hline 16 & Men & 256 & NT & 181 & ND & ND & ND \\
\hline 17 & Men & 181 & NT & 128 & NT & ND & ND \\
\hline 18 & Men & 8 & NT & NT & NT & ND & ND \\
\hline 19 & Men & 8 & NT & NT & NT & ND & ND \\
\hline 20 & Children & 8 & NT & NT & ND & ND & ND \\
\hline 21 & Children & 8 & NT & NT & NT & ND & ND \\
\hline
\end{tabular}

$\mathrm{C} 4$ strain by a polyclonal rabbit serum against EV-71 C1, which confirms that nAbs elicited against $\mathrm{C} 1$ are cross-protective against $\mathrm{C} 4$. We did not have access to antigenically divergent genotype B5 strains, which is unfortunate, as B5 strains were isolated from clinical specimens in Denmark in 2007 and in France in 2013 (8).

Neither the $\mathrm{C} 2$ strains nor the $\mathrm{C} 5$ strain could be neutralized by IVIg batches or individual serum samples. Because C2 has been persistently circulating in Europe since 1997 (10), it is unlikely that there has not been exposure to this genotype. In fact, a serum sample from our biobank obtained from a patient proven to be infected with EV-71 C2 could not neutralize the Dutch C2 strains either (data not shown). Large variations in $\mathrm{nAb}$ titers against $\mathrm{C} 2$, even in serum from children proven to be infected with $\mathrm{C} 2$, were observed by other research groups as well $(11,12,35,36)$. Variation in neutralizing activity could be explained by antigenic diversity among strains included in the analyses and strains to which patients or populations were exposed $(23,37)$. The $\mathrm{C} 2$ and $\mathrm{C} 5$ strains escaping neutralization in the current study differed from the neutralizable strains in VP3 residue 93 and VP1 residues 22 and 145 (C2) or 145 and 262 (C5). VP1 residue 145 has previously been identified as a key antigenic determinant, of which substitution can significantly affect the neutralizing activity $(23,38)$. Furthermore, VP1 22,145 , and 262 are among residues of which substitution through time has been suggested to be necessary for EV-71 persistence by generating antigenic novelty (5). Because the evolution of EV-71 genotypes is shaped by a continuous replacement of viral lineages over time, it will be of importance to further characterize the role of the identified mutations in determining antigenic diversity and to study whether the observed low nAbs titers against $\mathrm{C} 2$ and $\mathrm{C} 5$ reflect a real low seroprevalence or are a test artifact due to inclusion of antigenically divergent strains.

Cross-neutralizing activity against $\mathrm{C} 5$ in serum of $\mathrm{C} 4-$ infected humans has been reported, and from that perspective it is remarkable that the C5 strain escaped neutralization by the IVIg isolated in Vietnam that had high $\mathrm{nAb}$ titers against C4 $(12,39,40)$. However, it is complicated to compare results from studies that used different virus strains and serum from persons with different exposure histories, considering the co-circulation of different genotypes and the continuous evolution of EV-71 types with potentially novel antigenicity (5).

In conclusion, we showed the presence of high cross-nAb titers against EV-71 in IVIg batches and serum samples from Dutch donors. This finding implies that administration of Dutch IVIg could support recovery of a patient infected with an Asian EV-71 strain and that herd immunity induced by locally circulating strains could be cross-protective against widespread circulation and associated outbreaks of Asian strains in Europe. The identification of viruses that escape neutralization, however, warrants further research on antigenic diversity among EV-71 strains and emphasizes the importance of monitoring both the genetic and antigenic diversity of circulating strains.

\section{Acknowledgments}

We acknowledge the contribution of the patients who provided us with serum samples for virus research. We thank Lonneke van der Linden for her critical review of the manuscript.

The B3 SK-EV006 and B4 C7-Osaka strains were provided by H. Shimizu (National Institute of Infectious Diseases, Japan). Strains C4 75-Yamagata and strain C5 209-VN were provided 
by K. Mizuta (Yamagata Prefectural Institute of Public Health, Japan) and Drs. N.T.T. Thao and P.V. Tu (Pasteur Institute Ho Chi Minh City, Vietnam), respectively. Six IVIg batches composed of plasma from Dutch donors (Nanogam, Sanquin, The Netherlands) that were tested for cross-neutralizing capacity against EV-71 were provided by H. Zaaijer, Sanquin, The Netherlands; batches from Asian donors from Japan (Teijin Institute, Japan) and Vietnam (Green Cross Corporation, Vietnam) were provided by R. van Doorn, Hospital for Tropical Diseases, Ho Chi Minh City, Vietnam

The research described in this manuscript was funded by the FP7 Marie Curie IAPP consortium AIROPico.

Dr. van der Sanden is a postdoctoral researcher at the Laboratory of Clinical Virology, Department of Medical Microbiology, Academic Medical Center in Amsterdam. Her research focuses on prevalence and genetic diversity of human picornaviruses and picornavirus-host interactions in human $3 \mathrm{D}$ culture models.

\section{References}

1. Solomon T, Lewthwaite P, Perera D, Cardosa MJ, McMinn P, Ooi MH. Virology, epidemiology, pathogenesis, and control of enterovirus 71. Lancet Infect Dis. 2010;10:778-90. http://dx.doi.org/10.1016/S1473-3099(10)70194-8

2. Chong P, Liu CC, Chow YH, Chou AH, Klein M. Review of enterovirus 71 vaccines. Clin Infect Dis. 2015;60:797-803. http://dx.doi.org/10.1093/cid/ciu852

3. Saxena VK, Sane S, Nadkarni SS, Sharma DK, Deshpande JM. Genetic diversity of enterovirus A71, India. Emerg Infect Dis. 2015;21:123-6. http://dx.doi.org/10.3201/eid2101.140743

4. Yu H, Chen W, Chang H, Tang R, Zhao J, Gan L, et al. Genetic analysis of the VP1 region of enterovirus 71 reveals the emergence of genotype A in central China in 2008. Virus Genes. 2010;41:1-4. http://dx.doi.org/10.1007/s11262-010-0472-9

5. Tee KK, Lam TT, Chan YF, Bible JM, Kamarulzaman A, Tong CY, et al. Evolutionary genetics of human enterovirus 71: origin, population dynamics, natural selection, and seasonal periodicity of the VP1 gene. J Virol. 2010;84:3339-50. http://dx.doi.org/10.1128/JVI.01019-09

6. Akhmadishina LV, Eremeeva TP, Trotsenko OE, Ivanova OE, Mikhailov MI, Lukashev AN. Seroepidemiology and molecular epidemiology of enterovirus 71 in Russia. PLoS ONE. 2014;9:e97404. http://dx.doi.org/10.1371/journal.pone.0097404

7. Fischer TK, Nielsen AY, Sydenham TV, Andersen PH, Andersen B, Midgley SE. Emergence of enterovirus 71 C4a in Denmark, 2009 to 2013. Euro Surveill. 2014;19:38. http://dx.doi.org/10.2807/15607917.ES2014.19.38.20911

8. Mirand A, Molet L, Hassel C, Peigue-Lafeuille H, Rozenberg F, Bailly JL, et al. Enterovirus A71 subgenotype B5, France, 2013. Emerg Infect Dis. 2015;21:707-9.

9. Schuffenecker I, Henquell C, Mirand A, Coste-Burel M, Marque-Juillet S, Desbois D, et al. New introductions of enterovirus 71 subgenogroup C4 strains, France, 2012. Emerg Infect Dis. 2014;20:1343-6. http://dx.doi.org/10.3201/ eid2008.131858

10. van der Sanden S, Koopmans M, Uslu G, van der Avoort H. Epidemiology of enterovirus 71 in the Netherlands, 1963 to 2008. J Clin Microbiol. 2009;47:2826-33. http://dx.doi.org/10.1128/ JCM.00507-09

11. Chou AH, Liu CC, Chang JY, Jiang R, Hsieh YC, Tsao A, et al. Formalin-inactivated EV71 vaccine candidate induced cross-neutralizing antibody against subgenotypes B1, B4, B5 and C4A in adult volunteers. PLoS ONE. 2013;8:e79783.

http://dx.doi.org/10.1371/journal.pone.0079783

12. Huang ML, Chiang PS, Chia MY, Luo ST, Chang LY, Lin TY, et al. Cross-reactive neutralizing antibody responses to enterovirus 71 infections in young children: implications for vaccine development. PLoS Neg1 Trop Dis. 2013;7:e2067. http://dx.doi.org/10.1371/journal.pntd.0002067

13. Huang SW, Hsu YW, Smith DJ, Kiang D, Tsai HP, Lin KH, et al. Reemergence of enterovirus 71 in 2008 in Taiwan: dynamics of genetic and antigenic evolution from 1998 to 2008. J Clin Microbiol. 2009;47:3653-62. http://dx.doi.org/10.1128/JCM.00630-09

14. Kung SH, Wang SF, Huang CW, Hsu CC, Liu HF, Yang JY. Genetic and antigenic analyses of enterovirus 71 isolates in Taiwan during 1998-2005. Clin Microbiol Infect. 2007;13:782-7. http://dx.doi.org/10.1111/j.1469-0691.2007.01745.x

15. Mizuta K, Aoki Y, Suto A, Ootani K, Katsushima N, Itagaki T, et al. Cross-antigenicity among EV71 strains from different genogroups isolated in Yamagata, Japan, between 1990 and 2007. Vaccine. 2009;27:3153-8. http://dx.doi.org/10.1016/j.vaccine.2009.03.060

16. van der Sanden S, van der Avoort H, Lemey P, Uslu G, Koopmans M. Evolutionary trajectory of the VP1 gene of human enterovirus 71 genogroup B and C viruses. J Gen Virol. 2010;91:1949-58. http://dx.doi.org/10.1099/vir.0.019695-0

17. Zhang H, An D, Liu W, Mao Q, Jin J, Xu L, et al. Analysis of cross-reactive neutralizing antibodies in human HFMD serum with an EV71 pseudovirus-based assay. PLoS ONE. 2014;9:e100545. http://dx.doi.org/10.1371/journal.pone.0100545

18. van der Sanden SM, Koopmans MP, van der Avoort HG. Detection of human enteroviruses and parechoviruses as part of the national enterovirus surveillance in the Netherlands, 1996-2011. Eur J Clin Microbiol Infect Dis. 2013;32:1525-31. http://dx.doi.org/10.1007/ s10096-013-1906-9

19. Nix WA, Oberste MS, Pallansch MA. Sensitive, seminested PCR amplification of VP1 sequences for direct identification of all enterovirus serotypes from original clinical specimens. J Clin Microbiol. 2006;44:2698-704. http://dx.doi.org/10.1128/ JCM.00542-06

20. van der Sanden S. van EJ, Martin DP, van der Avoort H, Vennema H, Koopmans M. Detection of recombination breakpoints in the genomes of human enterovirus 71 strains isolated in the Netherlands in epidemic and non-epidemic years, 1963-2010. Infect Genet Evol. 2011;11:886-94. http://dx.doi.org/10.1016/j.meegid.2011.02.011

21. Hall TA. BioEdit: a user-friendly biological sequence alignment editor and analysis program for Windows 95/98/NT. Nucl Acids Symp Ser. 1998;41:95-8.

22. Foo DG, Ang RX, Alonso S, Chow VT, Quak SH, Poh CL. Identification of immunodominant VP1 linear epitope of enterovirus 71 (EV71) using synthetic peptides for detecting human anti-EV71 IgG antibodies in Western blots. Clin Microbiol Infect. 2008;14:286-8. http://dx.doi.org/10.1111/j.1469-0691.2007.01904.x

23. Huang SW, Tai CH, Fonville JM, Lin CH, Wang SM, Liu CC, et al. Mapping enterovirus A71 antigenic determinants from viral evolution. J Virol. 2015;89:11500-6.

24. Chang GH, Luo YJ, Wu XY, Si BY, Lin L, Zhu QY. Monoclonal antibody induced with inactivated EV71-Hn2 virus protects mice against lethal EV71-Hn2 virus infection. Virol J. 2010;7:106. http://dx.doi.org/10.1186/1743-422X-7-106

25. Foo DG, Alonso S, Phoon MC, Ramachandran NP, Chow VT, Poh CL. Identification of neutralizing linear epitopes from the VP1 capsid protein of Enterovirus 71 using synthetic peptides. Virus Res. 2007;125:61-8. http://dx.doi.org/10.1016/j.virusres.2006.12.005

26. Diedrich S, Weinbrecht A, Schreier E. Seroprevalence and molecular epidemiology of enterovirus 71 in Germany. Arch Virol. 2009;154:1139-42. http://dx.doi.org/10.1007/s00705-009-0413-x 
27. Rabenau HF, Richter M, Doerr HW. Hand, foot and mouth disease: seroprevalence of Coxsackie A16 and Enterovirus 71 in Germany. Med Microbiol Immunol (Berl). 2010;199:45-51. http://dx.doi.org/10.1007/s00430-009-0133-6

28. Honkanen H, Oikarinen S, Pakkanen O, Ruokoranta T, Pulkki MM, Laitinen $\mathrm{OH}$, et al. Human enterovirus 71 strains in the background population and in hospital patients in Finland. J Clin Virol. 2013;56:348-53. http://dx.doi.org/10.1016/j.jcv.2012.11.018

29. Ang LW, Phoon MC, Wu Y, Cutter J, James L, Chow VT. The changing seroepidemiology of enterovirus 71 infection among children and adolescents in Singapore. BMC Infect Dis. 2011;11:270. http://dx.doi.org/10.1186/1471-2334-11-270

30. Li W, Yi L, Su J, Lu J, Ke C, Zeng H, et al. Seroprevalence of human enterovirus 71 and coxsackievirus A16 in Guangdong, China, in pre- and post-2010 HFMD epidemic period. PLoS ONE. 2013;8:e80515. http://dx.doi.org/10.1371/journal.pone.0080515

31. Lu CY, Lee CY, Kao CL, Shao WY, Lee PI, Twu SJ, et al. Incidence and case-fatality rates resulting from the 1998 enterovirus 71 outbreak in Taiwan. J Med Virol. 2002;67:217-23. http://dx.doi.org/10.1002/jmv.2210

32. Tran CB, Nguyen HT, Phan HT, Tran NV, Wills B, Farrar J, et al. The seroprevalence and seroincidence of enterovirus 71 infection in infants and children in Ho Chi Minh City, Viet Nam. PLoS ONE. 2011;6:e21116. http://dx.doi.org/10.1371/journal.pone.0021116

33. Yu H, Wang M, Chang H, Lu J, Lu B, Li J, et al. Prevalence of antibodies against enterovirus 71 in children from Lu'an City in Central China. Jpn J Infect Dis. 2011;64:528-32.

34. Hassel C, Mirand A, Lukashev A, Terletskaia-Ladwig E, Farkas A, Schuffenecker I, et al. Transmission patterns of human enterovirus 71 to, from and among European countries, 2003 to 2013. Euro Surveill. 2015;20. http://dx.doi.org/10.2807/1560-7917. ES.2015.20.34.30005
35. Chia MY, Chung WY, Chiang PS, Chien YS, Ho MS, Lee MS. Monitoring antigenic variations of enterovirus 71: implications for virus surveillance and vaccine development. PLoS Negl Trop Dis. 2014;8:e3044. http://dx.doi.org/10.1371/journal.pntd.0003044

36. Wu CY, Wang HC, Wang KT, Weng SC, Chang WH, Shih DY, et al. Neutralization of five subgenotypes of Enterovirus 71 by Taiwanese human plasma and Taiwanese plasma derived intravenous immunoglobulin. Biologicals. 2013;41:154-7. http://dx.doi.org/10.1016/j.biologicals.2013.02.002

37. Chen Y, Li C, He D, Cheng T, Ge S, Shih JW, et al. Antigenic analysis of divergent genotypes human Enterovirus 71 viruses by a panel of neutralizing monoclonal antibodies: current genotyping of EV71 does not reflect their antigenicity. Vaccine. 2013;31:425-30. http://dx.doi.org/10.1016/j.vaccine.2012.10.032

38. Lee H, Cifuente JO, Ashley RE, Conway JF, Makhov AM, Tano Y, et al. A strain-specific epitope of enterovirus 71 identified by cryo-electron microscopy of the complex with fab from neutralizing antibody. J Virol. 2013;87:11363-70. http://dx.doi. org/10.1128/JVI.01926-13

39. Thoa LPK, Chiang PS, Khanh TH, Luo ST, Dan TN, Wang YF et al. Genetic and antigenic characterization of enterovirus 71 in Ho Chi Minh City, Vietnam, 2011. PLoS ONE. 2013;8:e69895. http://dx.doi.org/10.1371/journal.pone.0069895

40. Huang YP, Lin TL, Hsu LC, Chen YJ, Tseng YH, Hsu CC, et al. Genetic diversity and C2-like subgenogroup strains of enterovirus 71, Taiwan, 2008. Virol J. 2010;7:277. http://dx.doi.org/10.1186/1743-422X-7-277

Address for correspondence: Sabine M.G. van der Sanden, Academic Medical Center, Meibergdreef 9, 1105 AZ, Amsterdam, the Netherlands; email: s.m.g.vandersanden@amc.uva.nl

\section{SPOTLIGHT}

Ebola, previously known as Ebola hemorrhagic fever, is a rare and deadly disease caused by infection with one of the Ebola virus strains. Ebola can cause disease in humans and nonhuman primates (monkeys, gorillas, and chimpanzees).

Ebola is caused by infection with a virus of the family Filoviridae, genus Ebolavirus. There are five identified Ebola virus species, four of which are known to cause disease in humans. Ebola viruses are found in several African countries, and was first discovered in 1976 near the Ebola River in what is now the Democratic Republic of the Congo. Before the current situation, outbreaks have appeared sporadically in Africa.

The natural reservoir host of Ebola virus remains unknown. However, on the basis of evidence and the nature of similar viruses, researchers believe that the virus is animalborne and that bats are the most likely reservoir. Four of the five virus strains occur in an animal host native to Africa.

\section{http://wwwnc.cdc.gov/eid/page/ebola-spotlight}

